\title{
MODEL PEMASARAN BATU BATA RAMAH LINGKUNGAN BERDASARKAN PERSEPSI KONSUMEN
}

\author{
Anita O.T.D., Yunita Primasanti* \\ Program Studi Teknik Industri, Fakultas Sains, Teknologi, dan Kesehatan, Universitas Sahid \\ Surakarta, \\ Jl. Adi Sucipto No. 154, Jajar, Surakarta 57144
}

(Received: December 17, 2019/ Accepted: June 11, 2020)

\begin{abstract}
Abstrak
Batu bata merupakan salah satu komponen yang banyak digunakan dalam pendirian sebuah bangunan, baik perumahan, hotel, apartemen, industri, maupun fasilitas-fasilitas publik. Ancaman kerusakan ligkungan akibat munculnya industri batu bata tidak dapat dihindari jika bahan baku utama, batu bata, hanya menggunakan tanah liat. Oleh karena itu, saat ini sudah mulai muncul inovasi batu bata yang lebih ramah lingkungan dengan memanfaatkan limbah, seperti dilakukan salah satu pengrajin batu bata di daerah Kabupaten Karanganyar yang menggunakan limbah pabrik gula. Salah satu permasalahan yang umum dihadapi dalam implementasi produk ramah lingkungan adalah kurangnya kesadaran masyarakat yang disebabkan minimnya sumber informasi sehingga konsumen ragu membeli produk tersebut. Oleh karena itu, perlu dilakukan suatu penelitian mengenai model pemasaran batu bata ramah lingkungan dengan mempertimbangkan persepsi konsumen. Penelitian ini menggunakan metode STPD dan bauran pemasaran yang meliputi 8P. Hasil penelitian menunjukkan bahwa tiga atribut produk yang paling banyak dipertimbangkan adalah harga, fungsi produk, dan kelebihan produk berupa tahan gempa. Di sisi lain, responden paling banyak menginginkan batu bata yang aman, sehat, berasal dari produsen terpercaya, dan ramah lingkungan. Terkait karakteristik responden terhadap pemilihan batu bata ramah lingkungan, diketahui bahwa responden property syariah lebih menyukai batu bata ramah lingkungan.
\end{abstract}

Kata kunci: batu bata ramah lingkungan; STPD; bauran pemasaran

\begin{abstract}
Bricks are one component that is widely used in buildings, both housing, hotels, apartments, industry, and public facilities. The threat of environmental damage due to damage to the brick industry cannot be released if the main raw material for bricks uses only clay. Therefore, at this time has begun to appear more environmentally friendly bricks using waste, as did one of the brick craftsmen in Karanganyar Regency who used sugar mill waste. One that questions the common problem in implementing environmentally friendly products is reducing public awareness which reduces the source of information so as to make consumers hesitate to buy the product. Therefore, it is necessary to conduct research on environmentally friendly brick models by considering consumer perceptions. This research uses STPD method and marketing mix provided by $8 P$. The results showed that the three most preferred product attributes were price, product function, and product strength in the form of earthquake resistance. On the other hand, respondents most like bricks that are safe, healthy, requested from trusted manufacturers, and environmentally friendly. Regarding the characteristics of respondents regarding the selection of environmentally friendly bricks, Islamic property respondents are expected to prefer environmentally friendly bricks.
\end{abstract}

Keywords: environmentally friendly bricks; STPD; mix marketing

*Penulis Korespondensi.

E-mail: yprimasanti@gmail.com

\section{Pendahuluan}

Dunia industri saat ini dihadapkan pada tantangan isu lingkungan. Isu lingkungan berkaitan dengan kelangkaan sumber daya alam, pemanasan global, pengelolaan limbah, serta aturan-aturan lingkungan yang semakin ketat. Kebutuhan manusia 
yang semakin meningkat di berbagai daerah akan mengurangi sumber daya alam yang tersedia, terutama sumber daya tidak terbaharukan. Oleh karena itu, industri dituntut untuk bisa melakukan inovasi yang dapat mengarah pada green manufacturing. Tujuannya adalah keberlanjutan sehingga setiap sektor manufaktur harus memperhatikan bagaimana sumber daya alam yang digunakan saat ini dilestarikan agar terjamin ketersediaannya untuk generasi masa depan (Amaranti, dkk., 2017).

Salah satu industri yang dituntut untuk memperhatikan isu lingkungan adalah industri batu bata. Secara tahunan, permintaan terhadap properti komersial meningkat. Berdasarkan data Departemen Statistik untuk Triwulan I tahun 2018, kenaikan permintaan pada tahun 2018 terutama terjadi pada segmen perhotelan yang naik $10,38 \%$ dari tahun sebelumnya dan segmen apartemen, khususnya apartemen jual. Peningkatan ini membuat permintaan batu bata menjadi tinggi sehingga supply batu bata di beberapa daerah belum bisa memenuhi jumlah permintaan.

Ancaman kerusakan ligkungan akibat munculnya industri batu bata tidak dapat dihindari jika bahan baku utama batu bata hanya menggunakan tanah liat. Oleh karena itu, saat ini sudah mulai muncul inovasi batu bata yang lebih ramah lingkungan dengan memanfaatkan limbah pabrik gula, seperti penelitian Marwahyudi (2015). Batu bata tersebut memanfaatkan limbah pabrik gula di daerah Kabupaten Karanganyar.

Salah satu permasalahan yang umum dihadapi dalam implementasi produk ramah lingkungan adalah kurangnya awareness atau kesadaran masyarakat yang disebabkan minimnya sumber informasi (Mittal \& Sangwan, 2014). Hal ini menyebabkan masyarakat ragu dalam memilih produk baru, terutama produkproduk yang menggunakan bahan berupa limbah. Oleh karena itu, dalam memasarkan produk, produsen perlu memahami persepsi konsumen dalam menilai produk baru, terutama produk ramah lingkungan.

Beberapa penelitian tentang strategi pemasaran yang mempertimbangkan persepsi konsumen antara lain dilakukan oleh Rizki, dkk. (2013) untuk beras analog serta Waskito dan Witono (2013) untuk produk berwawasan lingkungan. Penelitian Harjoko (2015) juga mempertimbangkan persepsi konsumen ditambah analisis keyakinan dan kepercayaan. Selanjutnya Ronyastra (2017) melakukan pengembangan dengan penerapan STPD (Segmenting, Targetting, Positioning, dan Differentiating) dan marketing mix $8 P$ sebagai strategi pemasaran untuk produk Game online. Strategi marketing mix 8P mempengaruhi loyalitas pelanggan (Thalib, 2015) dan kepuasan konsumen (Vuthisopon, dkk., 2016).

Penelitian ini mengembangkan model pemasaran untuk produk berwawasan lingkungan yang lebih spesifik yaitu batu bata, dengan mempertimbangkan persepsi konsumen dan konsep marketing mix $8 P$. Aspek produktifitas dan kualitas dalam konsep marketing mix 8P menjadi penyempurna terhadap konsep 7P karena tidak bisa dipungkiri, pemasaran produk baru membutuhkan jaminan kualitas dan produktifitas dari produsennya. Penelitian ini diharapkan dapat memberikan strategi yang sesuai bagi pemasaran produk batu bata ramah lingkungan sehingga produk tersebut dapat menjadi produk substitusi yang lebih diminati oleh konsumen.

\section{Karakteristik Produk}

Bahan utama yang digunakan dalam pembuatan batu bata adalah tanah liat sedangkan bahan tambahan yang dicampurkan ke dalam bahan utama seperti dikutip dari penelitian Marwahyudi (2015), antara lain:

1. Sekam padi dan serbuk gergaji yang berfungsi untuk mempermudah proses pembakaran dan membentuk pori-pori.

2. Pasir, utamanya pasir kali berfungsi untuk mengurangi penyusutan dan mempermudah pengeringan.

3. Air berfungsi untuk mempermudah proses pengolahan, dapat melunakkan tanah liat yang keras dan menambah sifat plastis (workability).

Pada pembuatan batu bata ramah lingkungan, tanah liat yang menjadi bahan utama dapat digantikan sebagian oleh blotong sebagai limbah tebu. Blotong merupakan hasil endapan pada pemurnian nira yang saat ini lebih banyak digunakan sebagai pupuk di lahan tebu. Penggunaan blotong sebagai pengganti tanah liat dapat mengurangi volume penggunaan tanah yang bersifat non-renewable.

Produk batu bata ramah lingkungan ini juga memiliki fungsi tambahan yaitu lebih tahan terhadap gempa karena bentuk batu bata yang dibuat menyerupai huruf "Z" sehingga memiliki daya kait yang lebih kuat. Bentuk batu bata dapat dilihat pada Gambar 1.

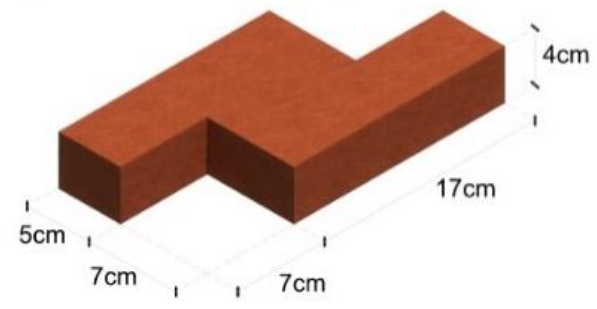

Gambar 1. Batu Bata Ramah Lingkungan dan Tahan Gempa

\section{Metode Penelitian}

Penelitian ini dilakukan berdasarkan alur pada Gambar 2. Penentuan atribut produk dilakukan melalui wawancara pendahuluan dengan beberapa responden dan studi literatur. Responden yang dipilih merupakan konsumen batu bata yang membeli produk untuk digunakan sendiri atau dijual kembali. Responden terdiri dari 3 kategori yaitu:

a. Pelaku usaha toko bangunan. Kategori responden ini membeli produk batu bata langsung dari pembuatnya. Persepsi pelaku usaha toko bangunan 


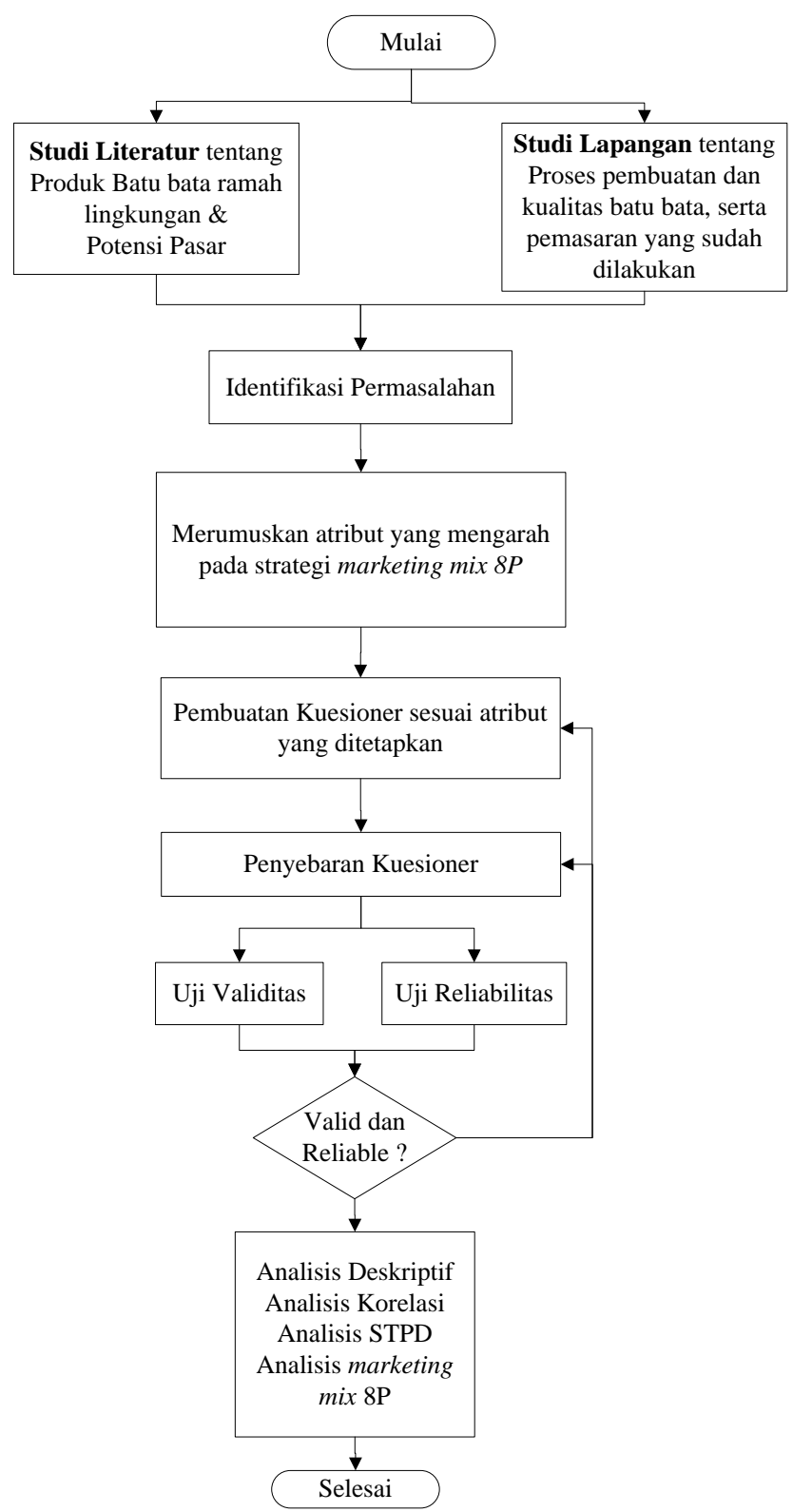

Gambar 2. Metode Penelitian

menggambarkan jenis batu bata yang biasa dibeli atau dicari oleh pengguna (end user).

b. Developer perumahan. Kategori responden ini dipilih karena dalam beberapa proyek pembangunan, jenis batu bata yang digunakan langsung ditentukan oleh developer.

c. Pengguna (end user). Kategori responden ini merupakan konsumen yang langsung membeli sendiri batu bata untuk membangun rumah yang ditinggalinya.

Berdasarkan hasil wawancara dan studi literatur, diperoleh 8 atribut yang akan diteliti berdasarkan persepsi konsumen. Data diperoleh melalui penyebaran kuesioner kepada 95 responden. Populasi yang digunakan adalah seluruh toko bangunan, developer, dan konsumen (end user) yang ada di 3 Kabupaten, yaitu Karanganyar, Sukoharjo, dan Solo. Ketiga kabupaten ini dipilih dalam penelitian ini karena letaknya paling dekat dengan produsen yang berada di Kabupaten Karanganyar.

Teknik pengambilan sampel yang digunakan adalah Quota Sampling. Sampel diambil dengan memberi jumlah (kuota) untuk masing-masing kelompok responden. Dalam penelitian ini, sampel untuk kelompok toko bangunan sebanyak $40 \%$, developer 20\%, dan konsumen (end user) $40 \%$. Kuesioner dibagi menjadi 2 bagian yaitu pernyataan tentang urutan prioritas atribut produk batu bata yang dipertimbangkan saat membeli dan pernyataan responden terhadap pembelian batu bata ramah lingkungan

\section{Hasil dan Pembahasan}

\subsection{Karakteristik Konsumen}

Karakteristik konsumen dapat menjadi informasi dalam menentukan segmentasi pasar dalam 


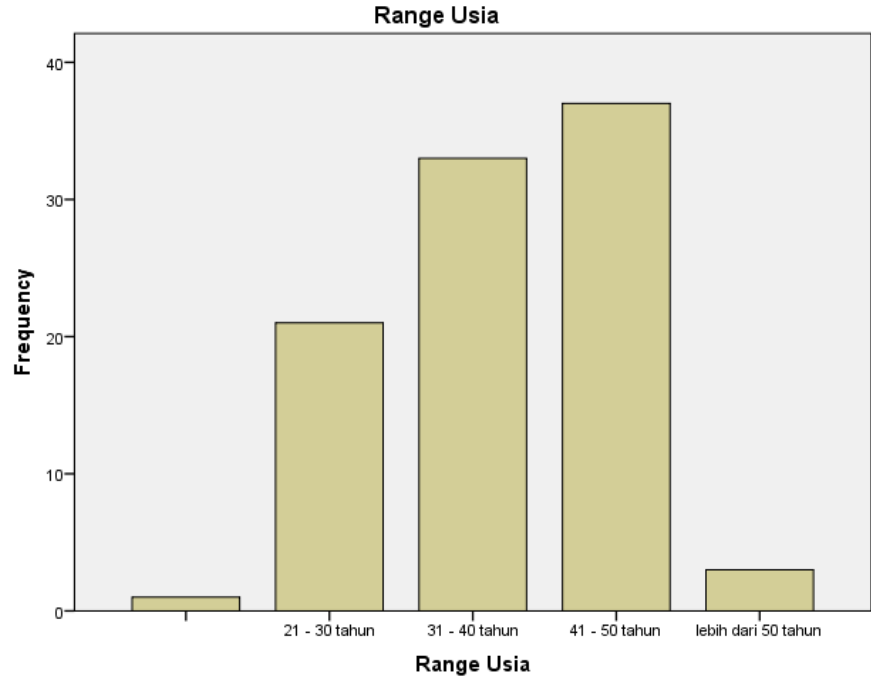

Gambar 3. Grafik Responden berdasarkan Range Usia

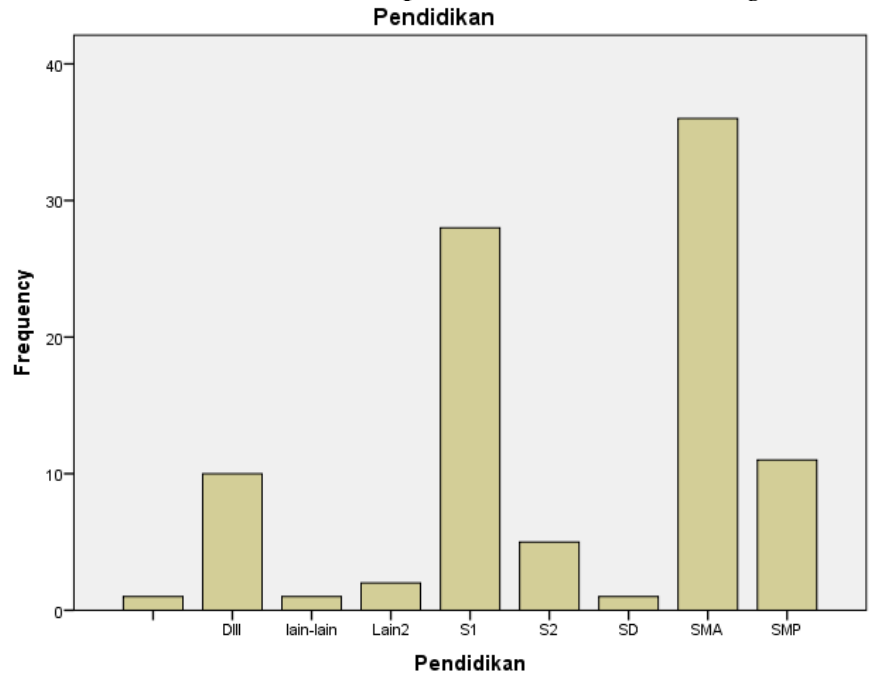

Gambar 5. Grafik Responden berdasarkan Tingkat Pendidikan

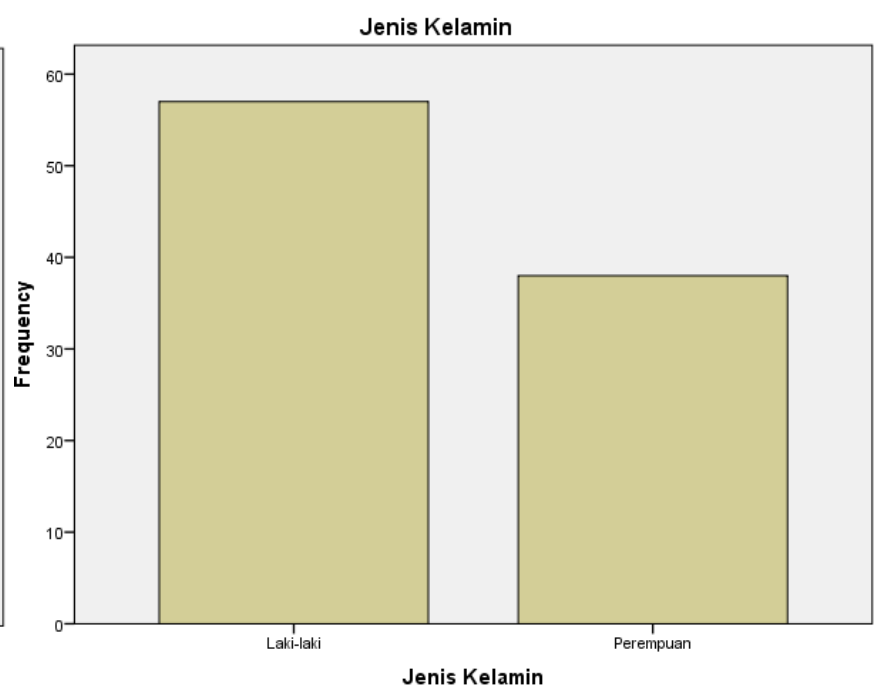

Gambar 4. Grafik Responden berdasarkan Jenis Kelamin Jenis Property

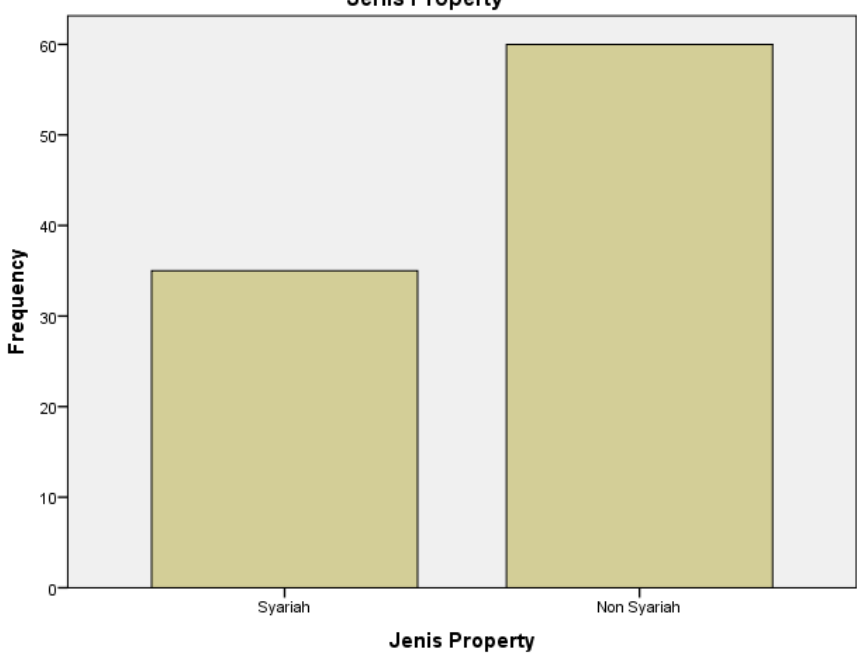

Gambar 6. Grafik Responden berdasarkan Jenis Property yang Diminati

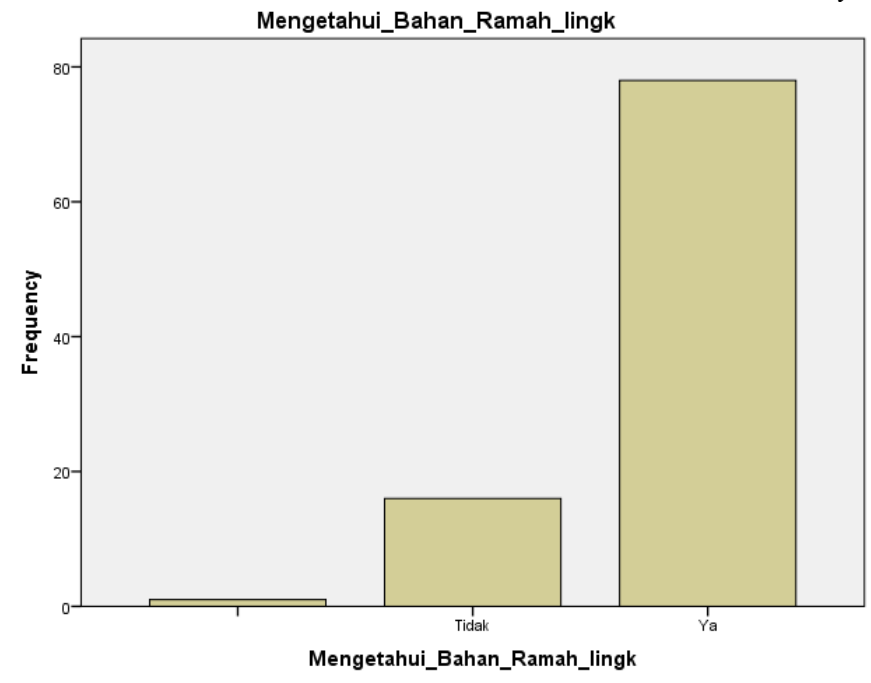

Gambar 7. Grafik Responden berdasarkan Pemahaman Terhadap Bahan Ramah Lingkungan

pemasaran produk. Beberapa karakteristik yang diteliti antara lain: usia, jenis kelamin, tingkat pendidikan, jenis property, dan pemahaman terhadap bahan ramah lingkungan. Secara grafis, hasil yang diperoleh terkait karakteristik responden dapat diamati pada Gambar 3 sampai Gambar 7. 
Tabel 1. Definisi Operasional Variabel

\begin{tabular}{|c|c|c|}
\hline No & Variabel & Definisi Oper \\
\hline 1 & Pem & $\begin{array}{l}\text { embuat batu bata yang memproduksi batu bata mulai dari bahan baku sampai menjadi } \\
\text { roduk yang siap dipasarkan. Dalam hal ini, pemasok mengetahui sumber bahan baku yang } \\
\text { gunakan. }\end{array}$ \\
\hline 2 & & lai uang yang harus dibayarkan konsumen untuk mendapatkan produk batu bata \\
\hline 3 & $\begin{array}{l}\text { Berfun } \\
\text { dengan }\end{array}$ & a telah diuji coba dalam pembangunan gedung dan terbukti berfungsi sebagaimana \\
\hline 4 & $\begin{array}{l}\text { Kemudahan } \\
\text { dalam } \\
\text { pemasangan }\end{array}$ & $\begin{array}{l}\text { Kemudahan yang diperoleh konsumen saat menggunakan batu bata, terutama ketika } \\
\text { pemasangan. Kemudahan ini sangat berkaitan dengan bentuk batu bata yang mudah dipasang } \\
\text { sehingga tidak mudah rusak }\end{array}$ \\
\hline 5 & $\begin{array}{l}\text { Ketahanan } \\
\text { terhadap } \\
\text { gempa / } \\
\text { kebakaran }\end{array}$ & $\begin{array}{l}\text { Kemampuan batu bata dalam mengurangi risiko kematian pada saat terjadi gempa / } \\
\text { kebakaran. Batu bata yang baik dapat menahan tembok agar tidak mudah roboh atau terbakar } \\
\text { sehingga kerugian dapat diminimalisir. }\end{array}$ \\
\hline 6 & $\begin{array}{l}\text { Ketersediaan } \\
\text { Produk }\end{array}$ & produk, tidak hanya untuk permintaan kecil tet \\
\hline 7 & $\begin{array}{l}\text { Kemasan } \\
\text { yang aman }\end{array}$ & $\begin{array}{l}\text { Kemasan yang menjaga bentuk serta kualitas produk di dalamnya. Selain itu, kemasan juga } \\
\text { memberikan keamanan bagi konsumen saat membawa produk. }\end{array}$ \\
\hline 8 & $\begin{array}{l}\text { Ramah } \\
\text { Lingkunga }\end{array}$ & $\begin{array}{l}\text { Sifat produk yang tidak membahayakan ekosistem atau lingkungan, terutama dari segi bahan } \\
\text { baku }\end{array}$ \\
\hline
\end{tabular}

Descriptive Statistics

\begin{tabular}{|l|r|r|r|r|r|}
\hline & N & Minimum & Maximum & Sum & Mean \\
\hline Pemasok & 95 & 1 & 8 & 426 & 4.48 \\
Harga & 95 & 1 & 8 & 623 & 6.56 \\
Berfungsi_baik & 95 & 1 & 8 & 516 & 5.43 \\
Mudah_dipasang & 95 & 1 & 7 & 427 & 4.49 \\
Tahan_gempa & 95 & 1 & 8 & 431 & 4.54 \\
Ketersediaan & 95 & 1 & 8 & 426 & 4.48 \\
Kemasan & 95 & 1 & 8 & 262 & 2.76 \\
Ramah_lingkungan & 95 & 1 & 8 & 309 & 3.25 \\
Valid N (listwise) & 95 & & & & \\
\hline
\end{tabular}

Gambar 8. Luaran SPSS untuk Analisis Deskriptif Delapan Atribut Produk

Gambar 3 menunjukkan bahwa jumlah responden paling banyak berada pada range usia 41-50 tahun yaitu sebanyak 37 responden atau $38,9 \%$. Gambar 4 menunjukkan bahwa laki-laki lebih banyak menjadi responden dengan jumlah 57 atau $60 \%$ responden. Gambar 5 menunjukkan bahwa responden terbanyak adalah yang memiliki tingkat pendidikan SMA atau sederajat yaitu 37,9\%. Sebagian besar mereka adalah penjual pada toko bangunan yang terbiasa menghadapi beragam konsumen yang mencari batu bata. Tingkat pendidikan terbanyak kedua yaitu S1 sebesar 28,7\%. Sebagian besar responden ini adalah end user atau konsumen.

Gambar 6 menunjukkan bahwa responden dengan keminatan terhadap properti non-syariah lebih tinggi yaitu sebanyak 60 responden sedangkan 35 responden memiliki keminatan terhadap property syariah. Gambar 7 menunjukkan bahwa 78 atau $82,1 \%$ responden sudah memahami tentang produk bahan bangunan yang ramah lingkungan.

\subsection{Atribut Produk}

Berdasarkan hasil wawancara langsung terhadap beberapa konsumen sebagai penelitian awal, diperoleh 8 atribut produk batu bata ramah lingkungan yang akan dikaji untuk melihat persepsi konsumen. Atribut tersebut dijelaskan pada Tabel 1.

Responden diminta untuk mengurutkan kedelapan atribut tersebut sesuai prioritas pertimbangan mereka dalam memilih batu bata. Prioritas pertama diberi nilai 8 dan seterusnya sampai prioritas kedelapan yang diberi nilai 1 . Berdasarkan hasil pengolahan data, diperoleh hasil pada Gambar 8. Berdasarkan penjumlahan nilai dari 95 responden untuk masing-masing atribut, diketahui bahwa faktor harga memiliki jumlah nilai tertinggi yaitu sebesar 623. Atribut dengan nilai tertinggi kedua dan ketiga adalah fungsi dan tahan gempa dengan nilai 516 dan 431. Atribut ramah lingkungan masih menempati urutan ke-7 berdasarkan prioritas konsumen dalam membeli batu bata.

\subsection{Persepsi Konsumen Terhadap Produk Batu Bata Ramah Lingkungan}

Data mengenai persepsi konsumen terhadap produk batu bata ramah lingkungan berupa data dengan skala Likert yang memiliki nilai 1 - 4 untuk jawaban sangat tidak setuju, tidak setuju, setuju, dan sangat setuju. Terdapat delapan pernyataan yang harus dijawab oleh responden terkait persepsi mereka 
terhadap kondisi-kondisi saat membeli batu bata ramah lingkungan. Delapan pernyataan tersebut masih terkait dengan 8 atribut yang ditentukan di awal.

Data hasil penyebaran kuesioner telah melalui uji reliabilitas dan validitas. Uji validitas menunjukkan apakah kuesioner tersebut mampu mengukur apa yang harus diukur, sedangkan uji reliabilitas menunjukkan konsistensi atas hasil ukuran walau digunakan untuk mengukur berkali-kali. (Trihendradi, 2012). Hasil uji reliabilitas dan validitas melalui SPSS versi 23 dapat dilihat pada Gambar 9 dan Gambar 10.
Berdasarkan Gambar 9, nilai Cronbach's Alpha yaitu 0,844 lebih besar dari 0,6 sehingga kuesioner dapat dinyatakan reliabel dalam pengumpulan data. Uji validitas yang ditampilkan dalam Gambar 10, menunjukkan bahwa nilai Pearson Correlation pada kolom Total_Penilaian (yang diberi tanda garis putusputus) lebih besar dari 0,3 untuk masing-masing pernyataan. Hal ini menandakan bahwa pertanyaanpertanyaan kuesioner dinyatakan valid dalam mengukur persepsi konsumen terhadap batu bata ramah lingkungan.

Reliability Statistics

\begin{tabular}{|c|r|}
\hline $\begin{array}{c}\text { Cronbach's } \\
\text { Alpha }\end{array}$ & N of Items \\
\hline .844 & 8 \\
\hline
\end{tabular}

Gambar 9. Hasil Uji Reliabilitas

Correlations

\begin{tabular}{|c|c|c|c|c|c|c|c|c|c|c|}
\hline & & Pernyataan 1 & Pernyataan 2 & Pernyataan 3 & Pernyataan 4 & Pernyataan 5 & Pernyataan 6 & Pernyataan 7 & Pernyataan 8 & $\begin{array}{c}\text { Total_penilai } \\
\text { an }\end{array}$ \\
\hline \multirow[t]{3}{*}{ Pernyataan 1} & Pearson Correlation & 1 & $.276^{\mathrm{kn}}$ & $.608^{112}$ & $.573^{\mathrm{nn}}$ & $.455^{\mathrm{Nx}}$ & $.449^{2 x}$ & $.710^{\mathrm{nn}}$ & $.333^{11}$ & $.751^{\mathrm{kn}}$ \\
\hline & Sig. (2-tailed) & & .007 & .000 & .000 & .000 & .000 & .000 & .001 & .000 \\
\hline & $N$ & 94 & 94 & 94 & 94 & 94 & 94 & 94 & 94 & 94 \\
\hline \multirow[t]{3}{*}{ Pernyataan 2} & Pearson Correlation & $.276^{\pi x}$ & 1 & $.260^{\circ}$ & $.472^{\mathrm{kn}}$ & $.220^{*}$ & $.279^{\mathrm{kn}}$ & $.327^{\mathrm{xn}}$ & $.290^{\mathrm{n}}$ & $.604^{\kappa *}$ \\
\hline & Sig. (2-tailed) & .007 & & .011 & .000 & .033 & .007 & .001 & .005 & .000 \\
\hline & N & 94 & 94 & 94 & 94 & 94 & 94 & 94 & 94 & 94 \\
\hline \multirow[t]{2}{*}{ Pernyataan 3} & Pearson Correlation & $.608^{\mathrm{nn}}$ & $.260^{*}$ & 1 & $.481^{\pi /}$ & $.604^{x+n}$ & $.384^{k x}$ & $.491^{x \pi}$ & $.437^{\mathrm{Nm}}$ & $.731^{\pi x}$ \\
\hline & N & 94 & 94 & 94 & 94 & 94 & 94 & 94 & 94 & 94 \\
\hline \multirow[t]{3}{*}{ Pernyataan 4} & Pearson Correlation & $.573^{\mathrm{kn}}$ & $.472^{\text {nx }}$ & $.481^{N \prime}$ & 1 & $.389^{x x}$ & $.377^{\mathrm{Nx}}$ & $.490^{x n}$ & $.426^{n \pi}$ & $.734^{x x}$ \\
\hline & Sig. (2-tailed) & .000 & .000 & .000 & & .000 & .000 & .000 & .000 & .000 \\
\hline & $\mathrm{N}$ & 94 & 94 & 94 & 94 & 94 & 94 & 94 & 94 & 94 \\
\hline \multirow[t]{3}{*}{ Pernyataan 5} & Pearson Correlation & $.455^{2 \pi}$ & $.220^{x}$ & $.604^{\mathrm{Nn}}$ & $.389^{\mathrm{kn}}$ & 1 & $.394^{\mathrm{xx}}$ & $.482^{\mathrm{nx}}$ & $.604^{\pi \times}$ & $.721^{\star x}$ \\
\hline & Sig. (2-tailed) & .000 & .033 & .000 & .000 & & .000 & .000 & .000 & .000 \\
\hline & $\mathrm{N}$ & 94 & 94 & 94 & 94 & 94 & 94 & 94 & 94 & 94 \\
\hline \multirow[t]{2}{*}{ Pernyataan 6} & Pearson Correlation & $449^{n}$ & $.279^{n x}$ & $.384^{201}$ & $.377^{\text {n1x }}$ & $.394^{x \times}$ & 1 & $.552^{x+1}$ & $.401^{x \times}$ & $.671^{x+}$ \\
\hline & N & 94 & 94 & 94 & 94 & 94 & 94 & 94 & 94 & 94 \\
\hline \multirow[t]{3}{*}{ Pernyataan 7} & Pearson Correlation & $.710^{\mathrm{m}}$ & $.327^{1 *}$ & $.491^{\prime \prime}$ & $.490^{\mathrm{m}}$ & $.482^{n+x}$ & $.552^{\mathrm{m}}$ & 1 & $.377^{\mathrm{Nn}}$ & $.764^{\prime \prime}$ \\
\hline & Sig. (2-tailed) & .000 & .001 & .000 & .000 & .000 & .000 & & .000 & .000 \\
\hline & $N$ & 94 & 94 & 94 & 94 & 94 & 94 & 94 & 94 & 94 \\
\hline \multirow[t]{3}{*}{ Pernyataan 8} & Pearson Correlation & $.333^{\mathrm{kn}}$ & $.290^{n x}$ & $.437^{\mathrm{Nn}}$ & $.426^{1 \times}$ & $.604^{n x}$ & $.401^{\pi \times}$ & $.377^{1 *}$ & 1 & $.690^{\mathrm{kn}}$ \\
\hline & Sig. (2-tailed) & .001 & .005 & .000 & .000 & .000 & .000 & .000 & & .000 \\
\hline & N & 94 & 94 & 94 & 94 & 94 & 94 & 94 & 94 & 94 \\
\hline \multirow[t]{3}{*}{ Total_penilaian } & Pearson Correlation & $.751^{\mathrm{N}}$ & $.604^{\mathrm{nx}}$ & $.731^{N 1}$ & $.734^{\mathrm{kn}}$ & $.721^{\pi x}$ & $.671^{\mathrm{kn}}$ & $.764^{\mathrm{Nn}}$ & $.690^{\mathrm{xn}}$ & 1 \\
\hline & Sig. (2-tailed) & .000 & .000 & .000 & .000 & .000 & .000 & .000 & .000 & \\
\hline & $\mathrm{N}$ & 94 & 94 & 94 & 94 & 94 & 94 & 94 & 94 & 95 \\
\hline
\end{tabular}

**. Correlation is significant at the 0.01 level (2-tailed)

*. Correlation is significant at the 0.05 level (2-tailed).

Gambar 10. Hasil Uji Validitas

Descriptive Statistics

\begin{tabular}{|l|r|r|r|r|r|}
\hline & N & Minimum & Maximum & Sum & Mean \\
\hline Produsen terpercaya & 94 & 2 & 4 & 332 & 3.53 \\
Terbukti baik digunakan & 94 & 1 & 4 & 301 & 3.20 \\
Pemasangan mudah & 94 & 2 & 4 & 321 & 3.41 \\
Aman gempa & 94 & 3 & 4 & 339 & 3.61 \\
Mudah didapat & 94 & 2 & 4 & 315 & 3.35 \\
Kemasan baik & 94 & 2 & 4 & 317 & 3.37 \\
Tidak Merusak alam & 94 & 2 & 4 & 327 & 3.48 \\
Harga rata-rata batu bata & 94 & 2 & 4 & 308 & 3.28 \\
biasa & 94 & & & & \\
Valid N (listwise) & & & & \\
\hline
\end{tabular}

Gambar 11. Luaran SPSS untuk Analisis Deskriptif Persepsi Konsumen Terhadap Batu Bata Ramah Lingkungan 


\begin{tabular}{|c|c|c|c|c|c|}
\hline \multicolumn{6}{|c|}{ Correlations } \\
\hline & & $\begin{array}{c}\text { Jenis } \\
\text { Kelamin }\end{array}$ & $\begin{array}{c}\text { Jenis } \\
\text { Property }\end{array}$ & $\begin{array}{c}\text { Ramah_lingk } \\
\text { ungan }\end{array}$ & Pernyataan 7 \\
\hline \multirow[t]{3}{*}{ Jenis Kelamin } & Pearson Correlation & 1 & $.267^{\pi \pi}$ & .112 & -.030 \\
\hline & Sig. (2-tailed) & & .009 & .281 & .775 \\
\hline & $N$ & 95 & 95 & 95 & 94 \\
\hline \multirow[t]{3}{*}{ Jenis Property } & Pearson Correlation & $.267^{\pi \pi}$ & 1 & $-.271^{\pi \times}$ & $-.349^{\pi \times}$ \\
\hline & Sig. (2-tailed) & .009 & & .008 & .001 \\
\hline & $N$ & 95 & 95 & 95 & 94 \\
\hline \multirow[t]{3}{*}{ Ramah_lingkungan } & Pearson Correlation & .112 & $-.271^{\pi \pi}$ & 1 & $.218^{x}$ \\
\hline & Sig. (2-tailed) & .281 & .008 & & .035 \\
\hline & $N$ & 95 & 95 & 95 & 94 \\
\hline \multirow[t]{3}{*}{ Pernyataan 7} & Pearson Correlation & -.030 & $-.349^{\pi \pi}$ & $.218^{\pi}$ & 1 \\
\hline & Sig. (2-tailed) & .775 & .001 & .035 & \\
\hline & $N$ & 94 & 94 & 94 & 94 \\
\hline
\end{tabular}

Gambar 12. Hasil Uji Korelasi

Pada kuesioner bagian kedua ini, terdapat satu responden yang tidak mengisi sehingga hanya tercatat 94 responden. Berdasarkan kolom jumlah (sum) sesuai analisis statistik deskriptif pada Gambar 11, diketahui bahwa tiga pernyataan dengan nilai tertinggi yaitu:

- Pernyataan bahwa konsumen lebih menyukai batu bata yang aman dan sehat (seperti aman terhadap gempa)

- Pernyataan bahwa konsumen lebih menyukai batu bata yang dipasok oleh produsen yang terpercaya

- Pernyataan bahwa konsumen lebih menyukai batu bata yang tidak menimbulkan kerusakan alam pada proses pembuatannya

Hasil pada Gambar 11 cukup berbeda dengan hasil yang ditunjukkan Gambar 8. Berdasarkan Gambar 8, faktor harga menjadi faktor yang paling dipertimbangkan dalam pemilihan produk batu bata. Di sisi lain, Gambar 11 menunjukkan bahwa harga yang sama atau lebih rendah (di bawah harga batu bata biasa) tidak menjadi poin utama responden dalam memilih batu bata ramah lingkungan. Hal ini dapat dilihat dari jumlah skor nilai pada pernyataan 8 (harga rata-rata batu bata biasa) yang menempati urutan terendah ke-2.

\subsection{Uji Korelasi}

Uji korelasi dilakukan untuk melihat hubungan antara karakteristik konsumen berupa jenis kelamin dan jenis property terhadap penilaian terhadap atribut ramah lingkungan. Hasil uji korelasi dapat dilihat pada Gambar 12. Berdasarkan Gambar 12 dapat dilihat bahwa jenis property memiliki hubungan yang signifikan terhadap pemilihan prioritas atribut ramah lingkungan. Nilai pearson correlation 0,271 dan 0.349 (lihat angka dengan garis merah) yang lebih besar dari nilai $r$ tabel 0,2604 juga menandakan bahwa antara pemilihan produk batu bata ramah lingkungan. Tanda negatif menunjukkan bahwa responden yang menyukai properti syariah (memiliki value $=1$ pada SPSS) memiliki penilaian yang semakin besar terhadap produk ramah lingkungan dibandingkan responden property non-syariah (value $=2$ pada SPSS).

\subsection{Analisis Segmenting, Targetting, Positioning, dan Differentiating (STPD) \\ a. Segmentation}

Pemasaran batu bata ramah lingkungan dapat menggunakan segmentasi psikologis berdasarkan keminatan konsumen terhadap jenis properti (syariah atau non-syariah). Konsumen dengan keminatan pada properti syariah cenderung lebih mudah memilih produk dengan kelebihan berupa ramah lingkungan dan aman terhadap gempa.

\section{b. Targeting}

Target pasar untuk produk batu bata ramah lingkungan dapat diprioritaskan pada konsumen perumahan syariah. Hal ini dilakukan karena kecenderungan konsumennya yang lebih terbuka terhadap produk ramah lingkungan dan tidak merusak alam.

\section{c. Positioning}

Berkaitan dengan positioning, produk batu bata ramah lingkungan ini lebih tepat ditawarkan dengan mengusung kelebihannya, tidak hanya ramah lingkungan tetapi juga lebih aman terhadap gempa. Oleh karena itu, dalam bahasa promosi dapat menggunakan kalimat "Produk batu bata yang ramah lingkungan dan aman terhadap gempa".

\section{d. Differentiation}

Produk batu bata ramah lingkungan sebenarnya telah memiliki kekhususan yang membedakannya dengan produk batu bata pada umumnya. Akan tetapi hal ini perlu lebih diyakinkan pada masyarakat bahwa dalam proses mapun fungsinya, batu bata ramah lingkungan benar-benar memiliki nilai lebih. 


\begin{tabular}{|c|c|c|c|c|c|c|}
\hline \multicolumn{7}{|c|}{ Correlations } \\
\hline & & Harga & $\begin{array}{c}\text { Tahan_gemp } \\
\text { a }\end{array}$ & $\begin{array}{c}\text { Ramah_lingk } \\
\text { ungan }\end{array}$ & Pernyataan 7 & Pernyataan 8 \\
\hline \multirow[t]{3}{*}{ Harga } & Pearson Correlation & 1 & $-.493^{\mathrm{k}}$ & $-.316^{k \prime}$ & -.106 & .144 \\
\hline & Sig. (2-tailed) & & .000 & .002 & .308 & .165 \\
\hline & $N$ & 95 & 95 & 95 & 94 & 94 \\
\hline \multirow[t]{3}{*}{ Tahan_gempa } & Pearson Correlation & $-.493^{\mathrm{n}}$ & 1 & .180 & $.291^{\pi \times}$ & .063 \\
\hline & Sig. (2-tailed) & .000 & & .080 & .004 & .543 \\
\hline & $N$ & 95 & 95 & 95 & 94 & 94 \\
\hline \multirow[t]{3}{*}{ Ramah_lingkungan } & Pearson Correlation & $-.316^{\pi n}$ & .180 & 1 & $.218^{n}$ & .011 \\
\hline & Sig. (2-tailed) & .002 & .080 & & .035 & .920 \\
\hline & $\mathrm{N}$ & 95 & 95 & 95 & 94 & 94 \\
\hline \multirow[t]{3}{*}{ Pernyataan 7} & Pearson Correlation & -.106 & $.291^{\mathrm{kn}}$ & $.218^{*}$ & 1 & $.377^{*}$ \\
\hline & Sig. (2-tailed) & .308 & .004 & .035 & & .000 \\
\hline & $N$ & 94 & 94 & 94 & 94 & 94 \\
\hline \multirow[t]{3}{*}{ Pernyataan 8} & Pearson Correlation & .144 & .063 & .011 & $.377^{\mathrm{Nn}}$ & 1 \\
\hline & Sig. (2-tailed) & .165 & .543 & .920 & .000 & \\
\hline & $\mathrm{N}$ & 94 & 94 & 94 & 94 & 94 \\
\hline
\end{tabular}

Gambar 13. Hasil Uji Korelasi

Model pemasaran STPD di atas dapat dicapai dengan baik jika produsen memperhatikan model bauran pemasaran $8 \mathrm{P}$ berikut:

\section{a. Produk}

Produk harus dideskripsikan dengan jelas dan benar-benar dibuktikan memiliki nilai lebih dibandingkan jenis batu bata pada umumnya. Karena produk batu bata ramah lingkungan masih termasuk produk inovasi baru yang akan beredar di pasaran, maka produsen perlu melakukan uji coba pemasangan batu bata pada satu bangunan utuh. Hal ini akan meminimalkan keragu-raguan konsumen terhadap fungsi utama batu bata.

\section{b. Price (Harga)}

Berdasarkan hasil pengolahan data, diketahui bahwa harga memiliki hubungan signifikan dengan atribut ramah lingkungan dan tahan gempa. Hal ini dapat dilihat pada Gambar 13 untuk nilai yang diberi garis merah. Hubungan yang terjadi adalah hubungan negatif, artinya konsumen yang memprioritaskan harga, tidak terlalu memperdulikan faktor ramah lingkungan maupun tahan gempa. Sebaliknya, konsumen yang cenderung memprioritaskan faktor ramah lingkungan, tidak terlalu mempedulikan harga. Hal ini menunjukkan, untuk segmen konsumen batu bata ramah lingkungan, harga tidak perlu terlalu murah atau sama dengan harga batu bata biasa. Produsen dapat sedikit menaikkan harga produk di atas harga batu bata biasa di pasaran. Akan tetapi, perlu dipahami bahwa responden yang menyukai produk ramah ligkungan juga menyukai harga yang tidak terlalu mahal (di atas harga batu bata biasa). Hal ini dapat diamati pada hubungan antara pernyataan 7 (menyukai produk ramah lingkungan) dan pernyataan 8 (menyukai harga yang tidak melebihi harga batu bata biasa).

Dalam penelitian Waskito dan Witono (2013) disebutkan bahwa konsumen sensitif terhadap harga ketika membeli produk ramah lingkungan dan mereka tidak mau membayar dengan harga premium untuk produk ramah lingkungan. Oleh karena itu, dalam memberikan harga, produsen jangan memilih harga yang tinggi atau jauh dari harga batu bata biasa.

\section{c. Place (Tempat)}

Pemasaran batu bata ramah lingkungan dapat difokuskan pertama kali untuk properti syariah. Oleh karena itu, produsen dapat mulai memasarkan produk pada komunitas-komunitas properti syariah. Selain itu, perlu diperhatikan lokasi pemasaran yang diutamakan berada di sekitar tempat produksi batu bata ramah lingkungan sehingga meminimalkan biaya transportasi. Produsen juga perlu memiliki kantor penjualan yang dapat dijadikan sebagai tempat bagi konsumen untuk melihat produk dan bertanya secara langsung tentang spesifikasi produk.

\section{d. Promotion}

Strategi pemasaran batu bata ramah lingkungan sebaiknya diawali dengan sosialisai kepada konsumen mengenai keutamaan produk ramah lingkungan. Promosi semacam ini lebih baik tidak dilakukan secara online tetapi langsung menjumpai calon konsumen sehingga meminimalkan keraguan konsumen. Alat promosi yang digunakan dapat berupa brosur yang dapat dibagikan untuk mengenalkan produk kepada masyarakat.

\section{e. People}

Produk batu bata ramah lingkungan dan tahan gempa merupakan produk baru dengan spesifikasi unik yang membutuhkan penjelasan ilmiah dan psikologis. Oleh karena itu, perlu ada orang-orang yang menguasai dengan baik tentang produk batu bata tersebut dalam menjelaskan kepada konsumen.

\section{f. Process}

Proses pemesanan batu bata harus dirancang dengan baik sehingga konsumen dapat secara langsung melakukan proses jual beli. Proses dapat dipermudah 
dengan menambahkan website resmi untuk proses jual beli dengan konsumen sehingga konsumen tidak perlu datang langsung ke kantor penjualan.

\section{g. Physical Evidence}

Salah satu alat pemasaran yang penting adalah adanya bukti fisik. Batu bata ramah lingkungan yang juga memiliki fungsi aman terhadap gempa ini memiliki bentuk yang berbeda dengan batu bata pada umumnya. Oleh karena itu, sangat peting bagi produsen untuk memiliki sampel batu bata yang siap digunakan.

\section{h. Productivity and quality}

Dalam meningkatkan produktivitas dan kualitas batu bata ramah lingkungan, produsen perlu memperhatikan lokasi tempat produksi. Sebaiknya tempat produksi yang dibangun, tidak jauh dari lokasi limbah yang digunakan. Selain itu, untuk mempertahankan kualitas, sebaiknya produsen menggunakan oven dalam pengeringan batu bata sehingga suhu pengeringan dapat distandarisasi. Hal ini penting untuk menjaga kualitas batu bata yang seragam.

\section{Kesimpulan}

Model pemasaran batu bata ramah lingkungan dengan memperhatikan persepsi konsumen dapat memberikan strategi pemasaran yang lebih menyeluruh karena tidak hanya memperhatikan aspek fisik produk tetapi juga aspek psikologi konsumen dalam menerima produk baru. Berdasarkan hasil penelitian, dapat disimpulkan bahwa atribut produk yang paling banyak menjadi prioritas dalam memilih batu bata adalah faktor harga, fungsi, dan adanya manfaat tambahan seperti tahan gempa. Selain itu, diketahui pula bahwa konsumen paling setuju pada pernyataan bahwa batu bata yang baik adalah yang aman, dipasok oleh produsen terpercaya, dan tidak menimbulkan kerusakan pada proses pembuatannya (ramah lingkungan). Beberapa poin tersebut menjadi dasar dalam menyusun model pemasaran STPD dan bauran pemasaran 8P.

\section{Daftar Pustaka}

Amaranti, Reni, dkk. 2017. Green Manufacturing : Kajian Literatur. Seminar dan Konferensi
Nasional IDEC 2017. Surakarta, 8-9 Mei 2017. ISSN: 2579-6429.

Harjoko, D.K. 2015. Analisis Sikap Konsumen Terhadap Produk Ramah Lingkungan (Green Product) Dan Produk Tidak Ramah Lingkungan (Non Green Product). Skripsi Program Studi Administrasi Bisnis, Universitas Pembangunan Nasional "Veteran" Yogyakarta.

Marwahyudi. 2015. Batu Bata Berkonstruksi. Seminar Nasional Teknik Sipil V Tahun 2015 - UMS. ISSN : 2459-9727.

Mittal, V. K., \& Sangwan, K. S. (2014). Prioritizing barriers to green manufacturing : environmental, social and economic perspectives. Procedia CIRP, 17, 559-564.

Rizki, D. A., dkk. 2013. Analisis Persepsi Konsumen dan Strategi Pemasaran Beras Analog (Analog rice). Jurnal Manajemen dan Organisasi Vol IV, No. 2, Agustus 2013.

Ronyastra, I Made. 2017. Perancangan Strategi Pemasaran Berdasarkan Perilaku Konsumen Daring Pada Multi Toys n Game Surabaya. Jurnal Teknik Industri HEURISTIC vol. 14 no. 2, Oktober 2017, hal. 97 - 106, ISSN: 16938232.

Thalib, Supriadi. 2015. The Effect of Services Marketing Mix and Customer Value on Satisfaction, Trust, and Loyalty. International Journal of Advanced Research (2015), Volume 3, Issue 9, 935- 949. ISSN 2320-5407.

Trihendradi, C. 2012. Step by Step SPSS 20 Analisis Data Statistik. Yogyakarta : ANDI OFFSET.

Vuthisopon, S., Chalitasrinuan, dan Fongsuwan, W. 2016. 8P'Sofmarketing Mix Towards Repurchase Intention Of Domestic Low Cost Airline In Thailand: A Conceptual Framework. Proceedings of $69^{\text {th }}$ The IIER International Conference, Beijing, China, 5 May 2016. ISBN: 978-93-86083-02-9.

Waskito, J. dan Witono, B. 2013. Mengembangkan Model Strategi Pemasaran Berwawasan Lingkungan. Proceeding Seminar Nasional dan Call For Papers Sancall 2013, Surakarta, 23 Maret 2013. ISBN: 978-979-636-147-2. 